The University of Akron

\title{
IdeaExchange@UAkron
}

July 2018

\section{The Walking Dramaturg: An Autoethnographic Methodology for Performance Documentation}

Giselle G. Garcia

University of Exeter, gg309@exeter.ac.uk

Please take a moment to share how this work helps you through this survey. Your feedback will be important as we plan further development of our repository.

Follow this and additional works at: https://ideaexchange.uakron.edu/docam

Part of the Digital Humanities Commons, Dramatic Literature, Criticism and Theory Commons, $\underline{\text { Performance Studies Commons, and the Theatre History Commons }}$

\section{Recommended Citation}

Garcia, Giselle G. (2018) "The Walking Dramaturg: An Autoethnographic Methodology for Performance

Documentation," Proceedings from the Document Academy: Vol. 5 : Iss. 1 , Article 5.

DOI: https://doi.org/10.35492/docam/5/1/5

Available at: https://ideaexchange.uakron.edu/docam/vol5/iss1/5

This Conference Proceeding is brought to you for free and open access by University of Akron Press Managed at IdeaExchange@UAkron, the institutional repository of The University of Akron in Akron, Ohio, USA. It has been accepted for inclusion in Proceedings from the Document Academy by an authorized administrator of

IdeaExchange@UAkron.For more information, please contact mjon@uakron.edu, uapress@uakron.edu. 
During the 2016 Karnabal Festival in the Philippines, Japanese artist Chikara Fujiwara presented his work Engeki Quest, which is a "series of flâneur-style tour projects guided by an adventure book with some instructions where the audience walks around freely to encounter the dreams, lives and ethos of the people, histories of the city" (BricolaQ, 2015). Later that year, I learned more about Wrights \& Sites based in the UK from Cathy Turner at the University of Exeter. She, together with Stephen Hodge, Phil Smith and Simon Persighetti, creates work focused on "people's relationships to places, cities, landscape and walking" (Wrights \& Sites, n.d.). In mid 2017, I saw a walking performance tour by UKbased company Situations called The Tale, "which was journey of discovery across the coast of Torbay, inspired by the writing of acclaimed author, Philip Hoare, who spent many childhood holidays there" (Situations, 2017).

It is then safe to say that walking has gone a long way from being a utilitarian, bodily action. Walking has invited performance makers to engage their audiences as co-creators, thus constituting a democratic mode of making and doing. Walking has become an artistic practice stemming from theater that fills a gap between the 19th-century flâneur and the Situationists' concept of the dérive from Guy Debord. The word flâneur was first used by Baudelaire and then developed by Walter Benjamin (2002) in the Arcades Project:

For the perfect flâneur ... It is an immense joy to set up house in the heart of the multitude, amid the ebb and flow ... To be away from home, yet to feel oneself everywhere at home; to see the world, to be at the center of the world, yet remain hidden from the world - such are a few of the slightest pleasures of those independent, passionate, impartial natures which the tongue can but clumsily define. The spectator is a prince who everywhere rejoices in his incognito ... The lover of universal life enters into the crowd as though it were an immense reservoir of electric energy. We might also liken him to a mirror as vast as the crowd itself; or to a kaleidoscope endowed with consciousness, which, with each one of its movements, represents the multiplicity of life and the flickering grace of all the elements of life. (p. 443)

The concept of the derive, however, was first published by Guy Debord (1956) in "The Theory of the Dérive." It immediately distances itself from the leisurely stroll of the flâneur as it involves a "playful-constructive behavior and awareness of psychogeographical effects, and are thus quite different from the classic notions of journey or stroll" (Debord, 1956, para. 2). While it is necessary to understand the persona of the walker as flâneur, it is just as important to analyze the walker as he dérives.

I propose to extend the act of walking not to end with creative practice and theory, but a creative method for documentation. Walking is an apt method, seeing as the origin of the word method in itself means "path." By recognizing 
that there is a figure that performs such a method, we can extend ideas about acts of documentation. The figure most likely to perform such an act is the dramaturg. Dramaturgy and dramaturg is in itself a slippery term in performance studies as "the concept of dramaturgy ... is intimately connected with the process of constructing a work and the interpretative analysis that was a part of that process" (Turner \& Behrndt, 2007, p. 97). They argue that dramaturgy is not entirely dependent on the existence of the dramaturg, but when the figure exists, concerns itself with the composition and context (Turner \& Behrndt, 2007, p. 98, p. 120). But more importantly, and necessary to understand in the context of writing performance histories, the dramaturg is not an authority that has all the answers. Turner and Behrndt write that the dramaturg is a map-maker, "but it nevertheless engaged in a journey of exploration" (2007, p. 184). This is an appropriate metaphor for understanding how dramaturgy is a methodology for making, and that both enact spatial expressions of finding pathways.

Given this, a dramaturg can function in several ways, but I argue that central to the dramaturg's practice are acts of cultural assemblage (Turner \& Behrndt 2007, p. 36). Dramaturgy as a term goes beyond the structural, compositional and contextual principles of drama. This idea is rooted in Mike Pearson and Michael Shank's Theatre/Archeology:

Dramaturgy, as cultural assemblage, works equally with settings, people, bodies, things, texts, histories, voices, architectures. In these connective networks that are the dramaturgical, it is usual to consider things and people as separate, their conjunction considered after their distinction. We propose instead the inseparability of people and things, values, etc. (Pearson \& Shank, 2001, pp. 89-90)

Finding structure within many forms and ideas however, as Turner and Behrndt (2007, p. 37) say, "could imply a tendency towards systemization and "management," which is antithetical to my own philosophy of dramaturgy as free exploration. Still, "it implies responsiveness, an awareness of the connections between things and is able both to facilitate and critique." (Turner \& Behrndt, 2007, p. 37) It is important to note that I have specific definitions for both dramaturgy and dramaturg for the purpose of this methodology: acts of dramaturgy pertain to cultural assemblage, and the walking dramaturg is a persona. The walking dramaturg borrows from auto-ethnography but is specific to an interdisciplinary field that crosses lenses with drama and sociology. Autoethnography, according to Hughes (2017, p. xii) "offers critically reflexive selfstorytelling that can illuminate (a) the internalized counternarratives that might disrupt the dominant cultural claims of neutrality, objectivity, color-blindness, and meritocracy." As a counter-narrative told by my subject-position as dramaturgwalker, I function to put together a cultural assemblage that archives and documents performance. The idea of the walking dramaturg works as a 
methodology for documentation because the narrative voice of the walking dramaturg offers a contribution to performance history, which can manifest in multifarious ways: thoughts, reflections, experiences, memories, images, texts, smells, sounds etc.

\section{Archaeologies and Mythogeographies: The Relationships of Time and Space}

I build on the idea of cultural assemblage further when Turner $(2004$, p. 373) argues that "each occupation, or traversal, or transgression of space offers a reinterpretation of it, even a rewriting. Thus space is often envisaged as an aggregation of layered writings - a palimpsest." Dramaturgy is an act of reconstruction and so involves constellating cultural assemblages and rewrites them, but not only within the confines of text and context (as in history) but within his or her position in space and time, as he or she performs an archeological dig of palimpsests in this spaces in which he or she walks.

A walking dramaturg has a material practice where negotiations of subject position, space, culture and structures are documented. In this sense, it has the same characteristics as Phil Smith's definition of mythogeographies as shared mythologies of space, contributing to the palimpsestic nature of theatre histories which can be personal, fictional and mythical on equal footing with factual, municipal history. The contemporary theater historian, just like the documenter then finds himself or herself at the intersection of practitioner, audience and scholar. Acts of dramaturgy must be found in the intersections of these three where expertise and curiosity live in harmony within the spaces in which they walk "since being-in-the-world includes a sense of the past, there is an archeological component within everyday life" (Turner, 2004, p. 376). Acts of historiography then must acknowledge the lived experience of the documenter. In many ways, this physicalizes a phenomenological approach to writing about performance. Arguably, the dramaturg as walker is the best way of documenting the researcher's experience because this subset of autoethnography takes into consideration the layers that exist in performances that need space and time excavation and exploration by a maker, historian, audience member and participant all at the same time. In so doing, the act of memory-making takes precedence over the so-called objectivity of a recording device. I am accepting the challenge of documentation "to consider the dynamic possibilities of the form, methods, purpose and spectatorship of their chosen documentation methods, and to assert its presence as part of an entirely valid creative research methodology" (Ledger, Ellis \& Wright, 2010, p. 183). The act of walking is the mode which I select to respond to this call precisely because the image of palimpsestic layers aligns with Smith's Mythogeography (2010), in the way "we construct an image of a past event, including those of the performance itself" where "forensic details 
of multiple narratives, poetic interpretation of fragmentary evidence" as "a reconstruction of space through its practice. Neither site not performance is fixed or graspable, yet both seemed to be glimpsed in passing" (Turner 2007, p. 377). This is particularly helpful in the act of walking whereby the layers of time and space are in constant movement in relation to the walker, depending on direction and speed, all the while experiencing the phenomenology of the present and presence. This is a direct contrast to what Mark Fisher $(2012$, p. 19) calls "teletechnologies" like the Internet as it radically collapses and compresses both space and time. Walking does the opposite-it expands space and time so that we might view ephemera with finer detail.

\section{The Politics of the Archive}

By studying the development of the archive, my work in documentation aims to rupture history's obsession with origin and linear pathfinding. Davis (2004) discusses how the historian's desire for the contextualization of archival materials usually stems from the need to fill research gaps. The problem with this objective is that scholars have different metrics of valuation for these so-called 'gaps.' Perhaps instead of manically trying to fill them, there's something to be said of the unfilled gap, its emptiness fuller of meaning than a "full" re/contextualized gap (Davis, 2004, p. 204). This is an important consideration in the methodology because my own personal subject position recognizes the limitations of my milieu.

However, I assert that my journey into documentation cannot be categorized as an illegitimate method of performance research. When Gale and Featherstone (2010, p. 24) claim that "there is no archive without politics of the archive," the existence of its hegemonic nature perpetuates the notion that an assigned authority decides which memory we should create and keep. However, performance studies also accepts the playful dynamism of memory-making as it embraces many sources of memory: process, product, memorabilia, ephemera, memoirs, critics, fans, performers, makers, etc. (Gale \& Featherstone, 2010, p. 24). We need to be aware that cultural memory-like the archive-also participates in a random inclusion and considered exclusion of material and are thus "susceptible to a state of incompleteness, to a kind of failure of memory; often contents are included only by chance" (Gale \& Featherstone, 2010, p. 24). This underscores the destabilization of the power of the archive as one that confers authority over memory. It is a journey in process or an act of wandering. By purposefully destabilizing the power of my own history as one with the desire to confer authority, my subject-position empowers and challenges others to voice theirs as well. Memory and experience then functions as an archive, and the elements which comprise them draw from several aspects of culture. The subject 
position's memory serves as a conduit for cultural assemblage. As a dramaturgwalker, with a specific history, writing my experience of this as a researcher allows for me to contribute to the archive and documentation of performance history.

When Schneider (2009) explores the connection between monuments and the archive, she also opens up a discussion of the way cities have developed. Famous walkers like Benjamin have explored cities like Paris where our contemporary notions of the place's history stems from their experienceBenjamin's reveries of the arcades being an example. When Scheider (2009, p. 54) says that "the monumental bears a close relation to the archive," one is compelled to unpack the word monument, whose etymology originating from Latin "to remind", "to advise" and "to warn" is often used as commemoration. It also used to mean something of a large scale, or the commemoration of the dead. Perhaps the reason we put such a premium on the archive is that it shares characteristics of the monument. They are created for the purpose of commemoration, the value of which gives it scale. In contrast, items that don't have preservative qualities decompose with time. But Schneider suggests that monuments and archives only exist inasmuch as they are in touch with that which keeps them alive (Schneider, 2009 p. 54). She draws the relationship to the city by referencing de Certeau (1984), and therefore challenges the reader to understand the agendas of the "monumental." If the archive is built as monuments are, then the methods to which it can be constructed can be questioned and altered. Memory is "monumentally" commemorated when there is an "interconstitution of hand on stone, flesh on bone" (Schneider, 2009 p. 54). Cities are then built so that inhabitants can exist within physicalized memories of that which they choose to live, enact, identify and remember. Its diverse range of walkers then exist in the various layers of monuments these cities choose to erect and destroy.

\section{The Rhizomatic Acts of Documentation}

What these diverse range of walkers as living inhabitants of the city have in common with the performance documenter is that they engage in practice as research, wherein their rhizomatic lived practices are a form of research. These multiple interpreters of the city all contribute to the archive the same way social media allows for individuals to contribute to its network. Ledger et al. (2010) write that:

documentation has become an implicit part of practice as research. What may be variously interpreted as a response to, a reflection upon, a recording, reworking or impression of live practice can take many forms and have a range of purposes. Issues of mediatisation, replication, remediation, interpretation and documentation's relationship with other 
forms of recording, response and analysis-most obviously critical writing - are further considerations. (Ledger et al., 2010, pp. 181-2)

This illustrates how the subject position of a performance researcher as dramaturg is a form of practice-as-research as they argue that "the documenter takes on the role of interpreter of the practice" (Ledger et al., 2010, p. 182). However, they continue and argue that "as researchers, we can acknowledge the effects and processes of mediatization, while simultaneously seeking out how documentation can form a new rendering of practice" (Ledger et al., 2010, p. 182). The walking dramaturg's individual experience is akin to the 19th century flâneur in that it is really a reflection of Walter Benjamin's narrative experience.

Further, Nicholson $(2009$, p. 256) likens the pace of walking with the pace of thought. And if walking is an act of thought, this can move in multi-directional, rhizomatic ways depending on where the subject position stands. For example, a flâneur, is less likely to associate his stroll with close analysis as he remains to be a detached observer. A dramaturg-walker however, aligns more with Debord's dérive whereby a drifter is less dependent on chance when looking at space psychogeographically, taking into account that urban spaces where the politics and design of the monument "have constant currents, fixed points and vortexes that strongly discourage entry into or exit from certain zones" (Debord, 1965, para. 2). In many ways, the latter recognized the limitations of the walking form, and the former takes on a privileged standpoint of freedom, a quintessentially 19th-century Western perspective.

\section{The Figure and Function of the Dramaturg Walker}

But the resurrection of the historical figure of the flâneur is not of mere romantic interest in the persona. D'Souza and McDonough (2006) write that:

the widespread contemporary fascination with nineteenth century Paris as a crucible for modernity (the dialectical notion of modernity first adumbrated by Benjamin in his great essays of the 1930s) dates back only about a generation, that is to the later 1970s and early 1980s" and so more than antiquarian interest, it served to reflect on our own "era of reaction and retreat. (D'Souza \& McDonough, 2006, p. 1)

This statement is still relevant in the era of current world events as one of "reaction and retreat." If (post)modernity is now characterized as the fight or flight period in world history, then it can only be described as severely ruptured not just in terms of time, but geography as well. Perhaps then my personal interest in the walking performance ethnographer stems from a desire to understand current phenomena from the ground on which I stand. I believe the dramaturg as a persona is only as important as its walk, and it is that walk itself that is a valuable form of documentation. The dramaturg's function is to culturally assemble 
material accrued over the experience of a walk and these "walked" cultural assemblages then contribute to performance history.

Wolff's (2006, p. 19) asserts that "the flâneur, the central figure of modernity was an inherently gendered male. And the account of urban experience, now seen through the eyes of the flâneur and his cohorts, instantly renders women invisible or marginal." She problematizes that theories of modernity have privileged the flâneur, because

the critic, for whom this figure looms so large, identifies strongly with him. The flâneur, is in fact, the critic, the writer, artist, sociologist - whose detached observations might well be reported in literary or visual texts. ... In general ... a crucial aspect of urban wandering is the "reading" of the urban environment and the production of texts-exactly the task of the social theorist and the urban ethnographer. In other words, the importance of the flâneur is, amongst other things, the self-importance of the sociologist of modernity, for whom this poetic figure serves a prototype. He has proved to be an attractive and suggestive figure, and one giving us a certain grasp of the peculiar features of life in the metropolisfragmentation, anonymity, speed and so on. (Wolff, 2006, p. 24)

She argues that by dispossessing the flâneur of his gender, and therefore his inherently masculine identity, he allows for emergence of the feminization of the flâneur. By making the flâneur dispossessed of gender or any kind of power, the figure becomes a mere inhabitant, whose views are no more important than her neighbors, allowing for multiple narratives and realities to emerge. Wolff then concludes that it is futile to even conceive the idea of female flânerie if the male flâneur cedes his position. To which I must respond: do we assume that there is no difference in the subject position of the walker? Rendell (2002) addresses this gender hegemony when she says that if a female walker unequivocally connotes prostitution by virtue of her freedom and mobility, then it is most definitely a cause of concern. This is by no means exclusive to 19th century France. It is present in most societies and cultures that value machismo, like the Philippines for example. In general, sons are free to go as they please, and are often gifted mobility in the form of a car, when they come of age. Whereas daughters have to prove themselves responsible and able, if not out of proven need, that they be allowed to go out, or drive on their own. But this gender bias can be read alternatively. When the female city walker is refocused with her own agenda for walking, she ceases to be an objectified figure, therefore enacting empowerment.

But more than the flâneur figure that calls attention to itself, it is the act of walking which I am arguing for, where the concern of walking is not so much directed at the self, but the outward interpretation of world, accepting his or her subject position-dériving without the dandy. 


\section{Documentation as Walking Performance}

Archiving must be mediated by the performance of documentation, in this specific case walking, as it is an act of thinking, act of processing, and an act of doing. If documentation is a series of acts, then surely this must constantly occur as it is being archived. This way, physical expressions of memories are in touch with that which keeps them alive. It is that which makes a city both a material artifact and a constitution of walking narratives. The dramaturg-walker straddles both the material and abstract form of the city as the very nature of theatrical performance necessitates attunement to both. Walking as a methodology is both reading and writing history - not limited to the confines of text and metaphor-because it grounds history in physical shapes, experiences and architectures challenging de Certeau's (1984) either/or binary.

In sum, this methodology is two-pronged: as a function and as a subjectposition, whereas the subject-position contributes to an understanding to one of the ways dramaturgy can function, the catalogue of such experience becomes a form of documentation in the archive of performance histories. It would be disingenuous, if not arguably unethical, to assume that these subject-positions don't exist, and so I ask: how can we understand documentation if we aren't aware of the fact that we participate in its performance?

\section{References}

Benjamin, W. The arcades project. (2002). Cambridge, MA: Harvard University Press.

BricolaQ. (2015, June 20). Engeki quest. Retrieved from http://bricolaq.com/?p=66

Debord, G. The theory of the dérive. (1956). Retrieved from http://library.nothingness.org/articles/all/en/display/314

de Certeau, M. (1984). The practice of everyday life. Berkeley: University of California Press.

D'Souza, A., \& McDonough, T. (2006). The invisible flaneuse?: Gender, public space and visual culture in nineteenth century Paris. Manchester, UK: Manchester University Press.

Fisher, M. (2012). What is Hauntology? Film Quarterly, 66, 16-24.

Gale, M. B., \& Featherstone, A. (2010). The imperative of the archive: Creative archive research. In B. Kershaw \& H. Nicholson (Eds.), Research methods in theatre and performance (pp. 17-40). Edinburgh, UK: Edinburgh University Press.

Hughes, S. A., \& Pennington, J. L. (2017). Auto-ethnography: Process, product and possibility for critical social research. Thousand Oaks, CA: Sage. 
Ledger, A. J., Ellis, S. K., \& Wright, F. (2010). The question of documentation: Creative strategies in performance research. In B. Kershaw \& H. Nicholson (Eds.), Research methods in theatre and performance (pp. 162185). Edinburgh, UK: Edinburgh University Press.

Nicholson, G. (2008). The lost art of walking: The history, science, philosophy and literature of pedestrianism. New York, NY: Penguin.

Pearson, M., \& Shanks, M. (2001). Theatre/archaeology. London, UK: Routledge.

Phelan, P. (1993). Unmarked: The politics of performance. London, UK: Routledge.

Rendell, J. (2002). The pursuit of pleasure: Gender, space and architecture in Regency London. London, UK: Athlone Press.

Schneider, R., \& Hopkins, D. J. (2009). Patricide and Passerby”. In S. Orr \& K. Solga (Eds.), Performance and the city (pp. 51-69). Basingstoke, UK: Palgrave Macmillan.

Situations. (2017). The tale at Torbay. Retrieved from http://www.situations.org.uk/projects/the-tale/

Smith, P. (2010). Mythogeography: A guide to walking sideways. Axminster, UK: Triarchy Press.

Taylor, D. (2003). The archive and the repertoire: Performing cultural memory in the Americas. Durham, NC: Duke University Press.

Turner, C., \& Behrndt, S.K. (2007). Dramaturgy and performance. Basingstoke, UK: Palgrave Macmillan.

Turner, C. (2004). Palimpsest or potential space? Finding a vocabulary for sitespecific performance. New Theatre Quarterly, 20, 373-390.

Wrights \& Sites. (n.d.). About. Retrieved from http://www.misguide/ws/about.html 